\title{
INTERCULTURAL COMMUNICATIVE COMPETENCE: L2 LEARNERS' PARTICIPATION ON DEBATING CLASS
}

\author{
${ }^{\# 1}$ Muliani, ${ }^{* 2}$ Dedi Sumarsono \\ ${ }^{\# 1}$ English Teacher, Faculty of Culture, Management and Business, Mandalika University of \\ Education, UNDIKMA, Indonesia \\ ${ }^{* 1}$ English Teacher, Faculty of Culture, Management and Business, Mandalika University of \\ Education, UNDIKMA, Indonesia
}

Corresponding Author Email: muliani@undikma.ac.id

\section{A B S T R A C T S}

Taboos in conversations will take place between speaker and hearer as the cultural awareness of the target language culture is not taken into account in the teaching and learning processes of English triggered this research to be conducted. This research deals with an analysis of intercultural communicative competence of L2 learners by means of applying Constructivists Model in which the preliminary description of how competent they are on L2 culture can be described. This research is qualitative research where eight students were arranged in debating class involved as the subject. Two debaters from Executive English Debate Community were engaged in this research as the team to construct the activities for the students. By providing an_observation checklist and questionnaire, the finding shows that the students actively exchange their ideas, they feel part of learning, they are able to develop problem-solving through peer collaboration, and they are able to develop new skills and knowledge from the other members of groups. It can be noted that the motions provided during the research, in which the L2 culture is considered, have helped the L2 learners to enhance their intercultural communicative competence seen from their active participation.

\author{
A R T I C L E I N F O \\ Article History: \\ Received: December, 2021
}

Revised: December, 2021

Published: December, 2021

\begin{tabular}{l}
\hline Keywords: \\
L2 Learners, \\
Intercultural Competence, \\
Constructivists Model, \\
Participation
\end{tabular}

How to cite: Muliani, M., \& Sumarsono, D. (2021). Intercultural Communicative Competence: L2 Learners' Participation on Debating Class. Jo-ELT (Journal of English Language Teaching) Fakultas Pendidikan Bahasa \& Seni Prodi Pendidikan Bahasa Inggris IKIP, 8(2), 198-206. doi:https://doi.org/10.33394/joelt.v8i2.4528

\section{INTRODUCTION}

In the development of the term, intercultural competence is labeled as "trans-cultural awareness" (Agnes, 2016: 2) which presents a great challenge for ELT teachers. They themselves do not always have the experience of multicultural immersion to rely on, and although foreign course books produced for the international market now offer a lot of interesting information about different cultures, they usually do not account for the learners' home culture and mother tongue. In other words, it can be noted that the need to have a certain proper approach to achieve what is called trans-cultural awareness is urgently needed. In intercultural communication, some English learners may know the literal meaning of an utterance but may fail to understand its contextual meaning or fail to accurately understand the speaker's intended force. In intercultural communication, being unaware of each other's respective social and cultural traditions, the interlocutors may participate in the communication with their own cultural values and use their own cultural systems to interpret 
the new situations they experience (Yun Long: 98). Furthermore, Hesar et al. (2012) state that no matter how proficient you are in all language skills in a foreign language or how perfect you speak that language it is difficult to communicate or negotiate with the native speakers of that language since you lack the cultural knowledge. In other words, the full mastery of a target language does not only involve the mastery of the language skills, patterns, and rules but also the target culture as it is supported by Sarem and Shirzadi (2014) states how important meaning in communication in which both the speaker utter the language and interlocutors need to understand the meaning of the communication. In Addition, it is also supported by Mahadi and Jafari (2012: 234) also add that there is a very close relationship between language and culture in general, and a specific language and its culture in particular.

Constructivist Model is a model proposed to be applied in this research modified from Sharma and Gupta (2013) in which the L2 culture is considered to be inserted on its applications. The steps of the model are as follows:

\section{Engage}

In the very first phase of the 5M Model of Constructivism is Engage, an attempt is made to activate students" prior knowledge by engaging them in the four motions provided by the researchers to get information about their previous knowledge. In this phase, students were engaged by asking a question, defining a problem, and showing a surprising event. Here, the role of the researchers was that of facilitators to create interest, generate curiosity, raise questions and encourage the students for response

\section{Explore}

In the second phase of 5E Model of Constructivism is Explore, an opportunity is given to the students to extend the knowledge of the first phase. Students were provided enough time to think freely, generate their own ideas, plan, investigate and organize collected information and record observations and ideas. They worked together in teams. Here, the role of the researchers was that of facilitators to observe, to listen to students as they interacted, to encourage them to work together, and to ask probing questions to redirect the students' investigation when necessary

\section{Explain}

In the third phase of 5E Model of Constructivism is Explain, students were encouraged to explain their observations and findings in their own words in the learning cycle. Researchers also asked for justification and clarification from students. In this phase, communication occurred between peers, the facilitators, or within the learner himself. This phase is also student-centered because students were given an opportunity to discuss, to listen critically the explanations given by the researchers and their peers, to raise questions about what they heard and to add their own explanations so as to engage in active learning.

\section{Elaborate}

In the fourth phase of 5E Model of Constructivism is Elaborate, an opportunity was given to the students to use their previous learned information as a vehicle to enhance a deeper and broader understanding and investigate new ideas. They practiced learned skills, refined them, and changed their behavior. Researchers encouraged the learners to apply and extend their understanding into new contexts.

\section{Evaluate}

The final phase of the 5E model of constructivism is Evaluate. This phase allowed the researchers to determine if the learner had attained an understanding of concepts. Evaluation occurred at all points along the continuum of the instructional process. The researchers evaluated the learners' achievement by asking open-ended questions, observation structured by checklists, and students' interviews. Students evaluated their progress by interacting to each other in this phase. 
The situation was constructed to get the students involved in a conversation. It is expected that the Cultural Experience Model for English Learners (Huang, 2014) brought the students from unconscious culture experience into a conscious experience where the description of how they participate, as part of Cultural Experience Model proposed by Huang (2014). Next to that, the situation arranged in their classroom can assist the researchers in gaining a preliminary description of their L2 cultural awareness.

The result of this research is expected to be able to contribute theoretically to those who are interested in understanding more about second language acquisition in which the consideration of both tense and culture of English as the target language is one of the most important things to consider to get the approximation to this target language. Furthermore, the result of this research is practically to contribute to the enhancement of tourism in West Nusa Tenggara. The result of this research could assist those who are taking part in the tourism area that the consideration of language and culture can be taken into account.

\section{RESEARCH METHOD \\ Research Design}

This research was be conducted in the form of a qualitative research design considering the Constructivist Model by Sharma and Gupta (2013). This qualitative research design focuses on seeing the case of the subject of the research to answer how competent they are in their intercultural communication seen from their speaking participation during the debating class by applying five elements of Constructivist Model.

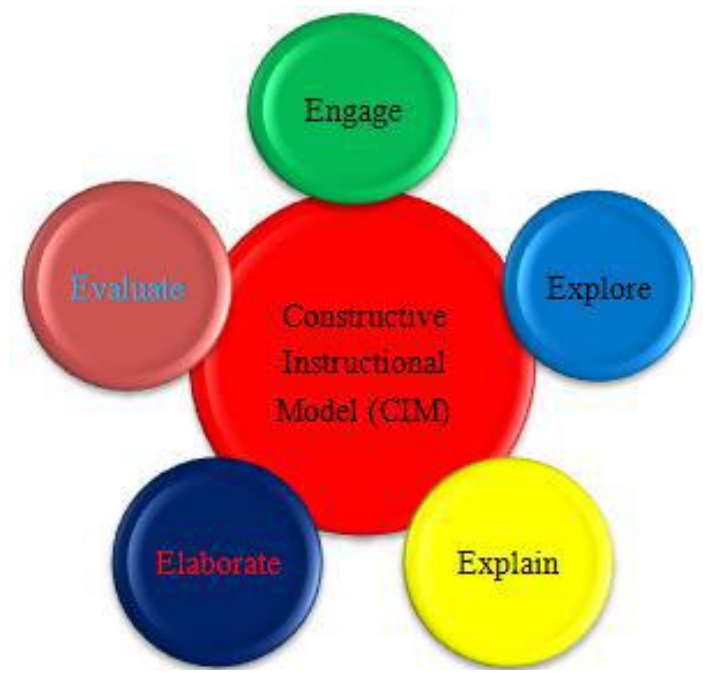

Figure 1. Five Elements of Constructivist Model.

\section{Subject}

This research involved eight (8) students of the English Language Education Program as the research subject. They were engaged in Debating Program as they went through 5 phases of the Constructivist Mode to see their participation as the aspect of the Cultural Experience Model for English Learners proposed by Huang (2014) as the indicator used to see their intercultural communicative competence of English.

\section{Instruments}

English Debating Topics with four motions chosen: 1) the house prefers online class to offline class 2) This house prefers to love someone by sparks rather than by choices 3) this house believes that Instagram brings more harm than good 4) this house believes that Santa should give a gift to all children, regardless of whether they were naughty or nice. The instruments brought the debaters/ learners to discuss and then think regarding the target 
language culture. By having those emotions, it was expected that the students would naturally participate. Observation Checklist was used during the debating program to check the students' while a questionnaire was used to strengthen the result of the observation.

\section{Data Analysis}

In analyzing the data, the qualitative description to answer the research questions was gained by considering the students' participation as one of the elements of four-Cultural Experience Model for English Learners. The students' participation was analyzed by analyzing both observation checklist and questionnaire. There are four questions provided to support the detail of the analysis of the students' participations adapted from the fourCultural Experience Model as follow:

a. I actively exchanged/did not actively exchange my ideas during the classroom discussion, why?

b. I felt/ I did not feel part of learning during the classroom discussion. Why?

c. I was/was not able to develop problem-solving skills through peer collaboration. Why?

d. I was/ was not able to develop new skills and knowledge from other members in my group. Why?

While the observation checklist to support the analysis of the data adapted from the cultural experience model used are in table 1 .

Table 1

Observation Checklist

\begin{tabular}{|l|l|l|}
\hline \multicolumn{1}{|c|}{ Students' participation } & Yes & No \\
\hline $\begin{array}{l}\text { She/he actively exchanges his/her } \\
\text { idea(s) during the classroom } \\
\text { discussion }\end{array}$ & & \\
\hline $\begin{array}{l}\text { She/he feels part of a learning } \\
\text { during the classroom discussion }\end{array}$ & & \\
\hline $\begin{array}{l}\text { She/he is able to develop } \\
\text { problem-solving skills through } \\
\text { peer collaboration }\end{array}$ & & \\
\hline $\begin{array}{l}\text { She/is able to develop new skills } \\
\text { and knowledge from other } \\
\text { members in my group }\end{array}$ & & \\
\hline
\end{tabular}

It can be noted that the data analysis is based on the answers of both the observation checklist (done by the researchers) and the questionnaires (done by the learners). The codification of the data was done first to ease the analysis of the data qualitatively supported by some related theories.

\section{RESEARCH FINDINGS AND DISCUSSION}

\section{Research Findings}

This part deals with the findings of the research to get the detail of the four aspects from the result of the questionnaire and the observation checklist regarding the students' participation during the debating class adapted from four-Cultural Experience Model.

From the eight subjects of the research, as the result of the observation, it can be seen that overall the students actively participated during the class. The result of the observation 
checklists was supported by the questionnaires regarding the L2 participation are shown as follows:

\section{Exchange their Ideas}

Table 2

Responses for Q1a: Exchanging Ideas

\begin{tabular}{|c|l|}
\hline Code & \multicolumn{1}{|c|}{ Responses for Q1: Exchanging Ideas } \\
\hline PS1Q1a & I actively giving my opinion during the discussion \\
\hline PS2Q1a & The class was fun and we asked each other actively \\
\hline PS3Q1a & $\begin{array}{l}\text { I actively exchanged ideas during the class and it really } \\
\text { improves my critical thinking }\end{array}$ \\
\hline PS4Q1a & $\begin{array}{l}\text { I actively exchanged my ideas during the class because } \\
\text { this debating class is proper for us to improve our critical } \\
\text { thinking }\end{array}$ \\
\hline PS5Q1a & $\begin{array}{l}\text { I actively exchanged my ideas during the class and I was } \\
\text { active sharing the ideas }\end{array}$ \\
\hline PS6Q1a & $\begin{array}{l}\text { I actively exchange my ideas during the discussion } \\
\text { because the debate assisted us to develop my critical } \\
\text { thinking }\end{array}$ \\
\hline PS7Q1a & $\begin{array}{l}\text { The tutor actively engaged with us, explained our } \\
\text { performance at the end every meeting, gave suggestion as } \\
\text { well. It helped to be active exchanging ideas }\end{array}$ \\
\hline PS8Q1a & $\begin{array}{l}\text { I actively exchanged ideas as I needed to be active during } \\
\text { the class }\end{array}$ \\
\hline
\end{tabular}

Table 2 shows that the learners actively exchanged their ideas during the class with various positive reasons. In brief, it can be noted that they actively exchanged their ideas during the debating class and were able to develop their L2 intercultural competence because 1) the motions lead them to actively exchange their ideas 2) the tutors are very supportive and well engaged with the learners, and 3) they need to be active as they need to improve their competence of L2.

\section{Feeling Part of Learning}

Table 3

Responses for Q1b: Feeling Part of Learning

\begin{tabular}{|c|l|}
\hline Code & \multicolumn{1}{|c|}{ Responses for Q2: Feeling Part of Learning } \\
\hline PS1Q1b & I feel part of learning because I need a lot of knowledge to learn \\
\hline PS2Q1b & As the atmosphere of the class was fun, I felt part of learning \\
\hline PS3Q1b & the tutors were so friendly that I felt part of learning \\
\hline PS4Q1b & $\begin{array}{l}\text { I felt part of learning because the tutors were smart and funny as } \\
\text { well }\end{array}$ \\
\hline PS5Q1b & $\begin{array}{l}\text { I felt part of learning because the tutors were so nurturing the } \\
\text { members of the debating class }\end{array}$ \\
\hline PS6Q1b & I felt part of learning as the tutor was so funny. I felt comfortable \\
\hline PS7Q1b & I felt part of the class as the tutor interacted a lot with us \\
\hline PS8Q1b & I enjoyed the class that I felt part of learning \\
\hline
\end{tabular}


Table 3 shows that most of the answers show that the learners feel part of learning because of the tutors who are friendly, nurtured, interact a lot with the class. In other words, the learners are feeling comfortable besides they also need a lot of knowledge to learn.

\section{Developing Problem Solving}

Table 4

Responses for Q1c: Developing Problem Solving

\begin{tabular}{|c|l|}
\hline Code & \multicolumn{1}{|c|}{ Responses for Q1c: Developing Problem Solving } \\
\hline PS1Q1c & $\begin{array}{l}\text { I was able to develop the problem solving based on the motion } \\
\text { given }\end{array}$ \\
\hline PS2Q1c & I develop the problem solving skills through discussion with peer \\
\hline PS3Q1c & $\begin{array}{l}\text { The peer collaboration helped me a lot to develop problem solving } \\
\text { regarding the motion }\end{array}$ \\
\hline PS4Q1c & $\begin{array}{l}\text { I was able to develop the problem solving because the motion } \\
\text { triggered us to find the solution through peer collaboration }\end{array}$ \\
\hline PS5Q1c & $\begin{array}{l}\text { I was able to develop problem as we had to find solution to the } \\
\text { existing problem given/motion }\end{array}$ \\
\hline PS6Q1c & $\begin{array}{l}\text { I was able to develop problem solving skill because through } \\
\text { discussion we could find the solution of the motion given }\end{array}$ \\
\hline PS7Q1c & $\begin{array}{l}\text { The collaboration with team helped me to develop the problem } \\
\text { solving }\end{array}$ \\
\hline PS8Q1c & $\begin{array}{l}\text { The coach was very helpful and it helped me a lot to develop my } \\
\text { problem solving }\end{array}$ \\
\hline
\end{tabular}

The responses in table 4 show that the learners are able to develop their problemsolving regarding the motions given as they work in team, with peer, and with a great assistance of the tutors.

\section{Developing New Skills}

Table 5

Responses for Q1d: Developing New Skills

\begin{tabular}{|c|l|}
\hline Code & \multicolumn{1}{|c|}{ Responses for Q1c: Developing Problem Solving } \\
\hline PS1Q1d & The debating class helps me a lot to develop my new skill \\
\hline PSQ1d & $\begin{array}{l}\text { As we learn together in team, I was able to develop new skill } \\
\text { from other members through discussion }\end{array}$ \\
\hline PS3Q1d & $\begin{array}{l}\text { As we exchange the ideas in group, I was able to develop my new } \\
\text { skill }\end{array}$ \\
\hline PS4Q1d & $\begin{array}{l}\text { I was able to develop my new skill because every single person } \\
\text { had to have an idea during the debating class }\end{array}$ \\
\hline PS5Q1d & $\begin{array}{l}\text { I was able to develop my2 new skill because we had a lot } \\
\text { interaction and we could exchange our ideas }\end{array}$ \\
\hline PS6Q1d & $\begin{array}{l}\text { I was able to develop my new skill because the interaction with } \\
\text { peer helped us a lot, we could exchange the ideas }\end{array}$ \\
\hline PS7Q1d & $\begin{array}{l}\text { I listened to different arguments of the other team and it is good } \\
\text { for developing my new skills }\end{array}$ \\
\hline PS8Q1d & $\begin{array}{l}\text { I am a new bee in debating class, but I learned a lot and felt able to } \\
\text { develop my new skill }\end{array}$ \\
\hline
\end{tabular}

Table 5 shows that all of the subjects stated that they can develop their new skills because the debating class leads them to work in team, to have a lot of interaction with 
others, and to listen to different arguments in which that kind of situation helps them a lot to develop their new skills, particularly in Speaking where the L2 culture is inserted.

\section{Discussion}

This part deals with the discussion of binding the finding with relevant theories or even previous research to get more detail elaboration of how are the students' L2 intercultural competence seen from their participation during the debating class where the motions and the situation provided were related to L2 culture. The codification of the data has been done to ease the data to be elaborated. $\mathrm{P}=$ participation, $\mathrm{S}=$ subject, $\mathrm{Q}=$ question.

Regarding the finding, it can be restated that the students actively exchange their ideas during the discussion due to some main reasons: 1) the motions lead them to actively exchange their ideas 2) the tutors are very supportive and well engaged with the learners, and 3) they need to be active as they need to improve their competence of L2. This is a good situation because the motion as the media, the situation, the teacher, should be very supportive to assist the learners in developing their speaking ability as stated by Rao (2019) that the classroom is the ideal platform to acquire good communication skills, especially, speaking skills. Moreover, his statement is also in line with the situation arranged in this research that the teachers have to understand the problems of the ELLs (English language learners) and try to implement various teaching strategies in their classrooms in order to develop their learners' speaking skills in English classrooms. Next to that, from the answer of PS8Q1a: I actively exchanged ideas as I needed to be active during the class. It is in line with what Rao (2019) states that in this globalization era, there have been drastic changes taking place all over the world in which these tremendous vicissitudes occur when people have a strong desire to achieve something. It is very clear that the learners need to achieve their goal of having good L2 speaking ability where the culture is considered through the situation inserted.

It is something expected that any learner participated well in speaking situation provided by feeling part of learning because by doing so, they were courageous to speak and get into the culture of the language being learned. It is proved the four-Cultural Experience Model with every single step on this application works because based on the finding, it can be seen that the learners feel part of learning. It can be restated from the answers of the subjects that the tutors who are friendly, nurtured, interact a lot with the class, which make them feel part of learning. It is really needed as stated by Hesar et al. (2012) that no matter how proficient you are in all language skills in a foreign language or how perfect you speak that language; it is difficult to communicate or negotiate with the native speakers of that language since you lack the cultural knowledge. Thus, feeling part of learning or feeling part of the L2 culture established by the teacher in the class assists the learners to feel part of it and it will ease them to get into the L2 culture. It is also strengthened by Rao (2014) in his study that it was also noticed that there is a deep sense of joy and fulfillment among the students because they have got an opportunity to enjoy learning English. Next to that, it is also good that the learners have got their internal motivation of being part of learning as it is supported by one of the subjects answer PS1Q1b: I feel part of learning because I need a lot of knowledge to learn.

Regarding the students' responses for Q1c: developing problem solving, it can be stated that the learners are able to develop problem-solving because of great team works. In other words, they work in team, with peer, and with a great assistance of the tutors. The tutors and peer collaboration are the important elements found as factors assisting L2 learners in developing problem-solving in their speaking class interaction, in this case, in the debating class. The answer for PS3Q1c: The peer collaboration helped me a lot to develop problem-solving regarding the motion shows how important peer collaboration in 
discussion is to assist learners to think creatively finding the solution for certain problem/motions given. It is in line with Johnson, et al (2013) about the importance of working collaboratively in group. Besides, collaborative learning is also in line with what Kuo, Chu \& Huang found (2015) in their research regarding collaborative learning through discussion.

Regarding PS8Q1c: The coach was very helpful and it helped me a lot to develop my problem solving, it shows that the good engagement of the tutors helps the learners a lot to develop their problem-solving. It is in line with one of the procedures of applying Constructivists Model proposed by Sharma \& Gupta (2013). Besides, the topic/motion also takes an important role in triggering the learners to develop the problem solving as it is supported by the result of PS4Q1c: I was able to develop the problem solving because the motion-triggered us to find the solution through peer collaboration.

Developing a new skill is also one of the aspects of questioning to see the students' participation during the debating class. The result also shows that this element is well established as the students' competence in L2 intercultural competence as it is supported by the finding that in the class, they have to work in team, to have a lot of interaction, and to listen to different arguments. In other words, supportive environment does help the learners to get into the approximation of the L2 culture through their speaking, their debating class, or through peer interaction as it is supported by Kondo (2018). He deals with some contributing factors to students' English speaking performance. Those factors are environment, peers, teachers, and technology use. All factors mentioned are in line with what this research has found except the use of technology which is not mentioned as the answers of the subject. This is also not something to deal with in this research, but the chosen topic does. In brief, to be able to negotiate or communicate welling in L2, a good atmosphere must be built up.

\section{CONCLUSION}

The research has been conducted to get a preliminary picture of how the students' L2 intercultural communicative competence is built up by means of applying Constructivist Model regarding their participation as one of the aspects of Cultural Experience Model. It can be concluded that the students actively participate during the class supported by the proper motions where L2 culture is inserted, the well-engaged teachers/tutors, and also peers assisting the learners to have a lot of interaction. All of those elements assist them to develop their intercultural communicative competence seen from the very active participation of the learners.

\section{ACKNOWLEDGMENTS}

Unspeakable gratitude is delivered to Research and Community Service of Mandalika University of Education (LPPM Universitas Pendidikan Mandalika) for the research funding that this research can be accomplished.

\section{REFERENCES}

Ágnes, M. (2016). Developing Transcultural Competence In A Digital ELT Course Material For Primary School Students. MultiScience. International Multidisciplinary Scientific Conference. DOI: 10.26649/musci.2016.143.

Hesar, M., P., K., M.Y., \& Zarfsaz, E. (2012). Why and how to apply culture in an EFL classroom?. International Conference on Language, Medias and Culture (IPEDR), 33, 68-72.

Huang, Y. (2014). Constructing Intercultural Communicative Competence Framework for English Learners. Cross-Cultural Communication, 10(1), pp. 97-101 DOI:10.3968/j.ccc.1923670020141001.3970. 
Johnson, D., \& Johnson, R. (2015). Cooperative Learning: Improving university instruction by basing practice on validated theory. Journal on Excellence in College Teaching. 25. 85-118.

Kondo, P. (2018). Contributing Factors to Students' English Speaking Performance at Universitas Klabat. Catalyst,17, 79-88.

Kuo, Y.-C \& Chu, Hui-Chun \& Huang, C.-H. (2015). A Learning Style-based Grouping Collaborative Learning Approach to Improve EFL Students' Performance in English Courses. Educational Technology and Society. 18(2). 284-298.

Mahadi, T., \& Jafari, M. (2012). Language and Culture. International Journal of Humanities and Social Science, 2(17), 230-235.

Sarem, S., \& Shirzadi, Y. (2014). A critical review of the Interactionist Approach to second language acqusition. Journal of Applied Linguistics and Language Research, 1(1), 6274.

Sharma, H., \& Gupta, P. (2016). Construstivist Approach for Teaching English: Making Sense of Paradigm Shift from the Traditional Approach. International Journal of Science and Research (IJSR), 5.

Rao, B. (2014). Use of Media as an Instructional Tool in English Language Teaching (ELT) at Undergraduate Level. International journal of English and Literature, 5(6), pp.141143.

Rao, S. (2019). The Importance of Speaking Skills in English Classrooms. Alford Council of International English \& Literature Journal(ACIELJ), 2(2), 1-12. 